\title{
Treadmill exercise ameliorates symptoms of attention deficit/hyperactivity disorder through reducing Purkinje cell loss and astrocytic reaction in spontaneous hypertensive rats
}

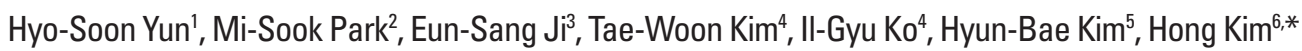 \\ 'Dague Veterans Hospital, Daegu, Korea \\ ${ }^{2}$ Department of Health and Welfare for the Elderly, Graduate School, Daegu Haany University, Gyeongsan, Korea \\ ${ }^{3}$ Department of Sport \& Health Science, College of Natural Science, Sangmyung University, Seoul, Korea \\ ${ }^{4}$ Department of Physiology, College of Medicine, Kyung Hee University, Seoul, Korea \\ ${ }^{5}$ Department of Taekwondo, College of Physical Education, Kyung Hee University, Seoul, Korea \\ ${ }^{6}$ Department of Oriental Sports Medicine, College of Biomedical Science, Daegu Haany University, Gyeongsan, Korea
}

Attention deficit/hyperactivity disorder (ADHD) is a neurobehavioral disorder of cognition. We investigated the effects of treadmill exercise on Purkinje cell and astrocytic reaction in the cerebellum of the ADHD rat. Adult male spontaneously hypertensive rats (SHR) and Wistar-Kyoto rats (WKYR) weighing $210 \pm 10 \mathrm{~g}$ were used. The animals were randomly divided into four groups $(n=15)$ : control group, ADHD group, ADHD and methylphenidate (MPH)-treated group, ADHD and treadmill exercise group. The rats in the MPH-treated group as a positive control received $1 \mathrm{mg} / \mathrm{kg}$ MPH orally once a day for 28 consecutive days. The rats in the treadmill exercise group were made to run on a treadmill for 30 min once a day for 28 days. Motor coordination and balance were determined by vertical pole test. Immunohistochemistry for the expression of calbindinD-28 and glial fibrillary acidic protein (GFAP) in the cerebellar vermis and Western blot for GFAP, Bax, and Bcl-2 were con- ducted. In the present results, ADHD significantly decreased balance and the number of calbindin-positive cells, while GFAP expression and $\mathrm{Bax} / \mathrm{Bcl}-2$ ratio in the cerebellum were significantly increased in the ADHD group compared to the control group $(P<0.05$, respectively). In contrast, treadmill exercise and MPH alleviated the ADHD-induced the decrease of balance and the number of calbindine-positive cells, and the increase of GFAP expression and $\mathrm{Bax} / \mathrm{Bcl}-2$ ratio in the cerebellum $(P<0.05$, respectively). Therefore, the present results suggested that treadmill exercise might exert ameliorating effect on ADHD through reduction of Purkinje cell loss and astrocytic reaction in the cerebellum.

Keywords: Attention deficit/hyperactivity disorder, treadmill exercise, Vertical pole test, Cerebellum, Purkinje cell

\section{INTRODUCTION}

Attention deficit/hyperactivity disorder (ADHD) is one of the most common childhood neurobehavioral disorders characterized by hyperactivity, impulsivity, and attention deficit (Banaschewski et al., 2004). It affects approximately $5-12 \%$ of children (Bedford et al., 1979; Berridge et al., 2006) which frequently persist into adolescence and adulthood (Banaschewski et al., 2004; Bethancourt et al., 2009). For this reason, the etiology of ADHD has been extensively studied using animal and humans (Kim et al., 2011; Passarelli et al., 2013; Wang et al., 2013) and then the pathophysiology of ADHD are suggested to be closely associated with anatomical and functional abnormalities in frontal-striatalcerebellar circuits (Giedd et al., 2001). Of these circuits, many studies have shown that cerebellum is one of the most important parts of the brain related to the ADHD.

The cerebellum is as a key anatomical structure underlying normal attentional and cognitive control mechanisms. Previous stud-
${ }^{*}$ Corresponding author: Hong Kim

Department of Oriental Sports Medicine, College of Biomedical Science, Daegu

Haany University, 1 Hanuidae-ro, Yugok-dong, Gyeongsan 712-715, Korea

Tel: +82-53-819-1468, Fax: +82-53-819-1264, E-mail: joshua@dhu.ac.kr

Received: February 4, 2014/ Revised: February 12, 2014/ Accepted: February 19, 2014
This is an Open Access article distributed under the terms of the Creative Commons Attribution Non-Commercial License (http://creativecommons.org/licenses/by-nc/3.0/) which permits unrestricted non-commercial use, distribution, and reproduction in any medium, provided the original work is properly cited. 
ies have shown that the cerebellum is thought to play a crucial role in cognitive function, particularly in learning, attention, and emotional regulation (Ivry et al., 2002; Schmahmann and Sherman1998). On the other hand, cerebellar impairment may contribute to the cerebellum cognitive and affective syndrome (CCAS) (De Smet et al., 2013). Related to the ADHD, several studies have reported that the symptoms of ADHD has strongly related to the dysfunction of cerebellar circuits (Giedd et al., 2001) induced by reduction of cerebellar volume (Berquin et al., 1998; Castellanos et al., 2002; Semrud-Clikeman et al., 2000). In addition, the reduced size of cerebellar vermis was associated with the clinical deficits by ADHD (Ashtari et al., 2005; Buderath et al., 2009; Mackie et al., 2007). Recently, both functional and morphometric cerebellar abnormalities have been consistently demonstrated in ADHD (Soliva et al., 2009).

Purkinje neurons in the cerebellum play crucial role in movement, coordination, and cognitive function including motor learning (Passarelli et al., 2013; Seo et al., 2010; Zhang et al., 2013). It has been reported that the impairment of Purkinje cells causes cerebellar ataxia (Jones et al., 2010; Lu et al., 2011). In addition, loss of Purkinje cells is related to the brain disorder such as Alzeheimer's disease and ADHD (Fukutani et al., 1996; Passarelli et al., 2013). Despite such findings involving the cerebellum in response to a brain disorder, the influence of ADHD on Purkinje cell loss and astrogliosis in the cerebellum remains unclear.

In clinic, pharmacological stimulants such as norepinephrine agonists (Banaschewski et al., 2004) and methylphenidate (MPH) and indirect dopaminergic agonist were used to reduce the symptoms of ADHD. Of them, MPH is the most popular medication because of its effects on ADHD (Bethancourt et al., 2009). These stimulants, however, sometimes exert no effectiveness or induce side effect, often restrain their continued use (Banaschewski et al., 2004). For this reason, the physical activity or regular exercise get attention as a kind of non-medicinal effective method for reducing the symptom of ADHD.

Many studies have reported that exercise improves motor performance, learning, memory, and cognitive function in animals (Erickson et al., 2013; Jee et al., 2008; Kim et al., 2010a; Radak et al., 2001). Related to the Purkinje cells of cerebellum, treadmill exercise increased dendritic spine plasticity by inducing the changes of Purkinje cell in adult rat (González-Burgos et al., 2011). Another study also showed that physical exercise also improved working speed and social behavioral problems, and diminished hyperactivity in ADHD children (Majorek et al., 2004).

Although the beneficial effects of physical exercise on abnormal brain function are well documented, there is no available study for the effect of exercise on ADHD in relation with Purkinje cells and astrocytic reaction in the cerebellum. Therefore, we investigated the effects of treadmill exercise on Purkinje cell loss and astrocyte activation in the cerebellum of the ADHD rat.

\section{MATERIALS AND METHODS}

\section{Experimental animals and treatments}

Adult male spontaneously hypertensive rats (SHR) weighing $210 \pm 10 \mathrm{~g}$ were used as the ADHD animal model, because the SHR displays the major symptoms of ADHD such as hyperactivity. SHR was selected only when showed hyperactivity in open field test. Meanwhile, Wistar-Kyoto rats (WKYR) weighing 210 10 $\mathrm{g}$ were used as the control in this study, according to the previous study (Sagvolden, 2000). The rats were housed under controlled temperature $\left(20 \pm 2^{\circ} \mathrm{C}\right)$ and lighting conditions (07:00 to 19:00), with food and water made available ad libitum throughout the experiments. Prior to the exercise and drug treatment, we tested the effects of different amount of treadmill exercise on the hyperactivity, as pre-test. The animals were randomly divided into four groups $(\mathrm{n}=15)$ : control group, ADHD group, ADHD and methylphenidate (MPH)-treated group, ADHD and treadmill exercise group. The rats in the MPH-treated group received $1 \mathrm{mg} / \mathrm{kg}$ MPH (Ritalin $^{\circledR}$, Novartis Co., Bassel, Switzerland) orally once a day for 28 consecutive days, according to the previous study (Lijffijtet et al., 2005). All animal procedures were performed in accordance with the animal care guidelines of the National Institutes of Health (NIH) and the Korean Academy of Medical Sciences.

\section{Vertical pole test}

For the vertical pole test, the animal was placed face up on a cloth-tape-covered pole $(3.0 \mathrm{~cm}$ diameter, $150 \mathrm{~cm}$ length), which was held in a horizontal position, then the pole was gradually lifted to a vertical position and the time a rat stayed on the pole was recorded for a maximum of $180 \mathrm{sec}$. In this test, the animal with deficits in motor coordination and balance will fall off the pole (Tanriover et al., 2010).

\section{Treadmill exercise protocol}

The rats in the treadmill exercise group were subjected to run on a treadmill for 30 min once a day, five times a week, for 28 days. Exercise load for the running group consisted of running at a speed of $2 \mathrm{~m} / \mathrm{min}$ for the first $5 \mathrm{~min}$, at a speed of $5 \mathrm{~m} / \mathrm{min}$ for the next $5 \mathrm{~min}$, and then at a speed of $8 \mathrm{~m} / \mathrm{min}$ for the last $20 \mathrm{~min}$, with 
the $0^{\circ}$ inclination. This intensity corresponded to the low-intensity treadmill exercise (\% maximal oxygen consumption) of rats in this age (Bedford et al., 1979).

\section{Tissue preparation}

The rats were sacrificed 29 days after the starting of experiment, immediately after vertical pole test. To begin the sacrifice process, animals were fully anesthetized using Zoletil $50^{\circledR}(10 \mathrm{mg} / \mathrm{kg}$, i.p.; Vibac Laboratories, Carros, France). The anesthetized rats were transcardially perfused with $50 \mathrm{mM}$ phosphate-buffered saline (PBS), and fixed with a freshly prepared solution consisting of 4\% paraformaldehyde (PFA) in $100 \mathrm{mM}$ phosphate buffer (PB) at $\mathrm{pH}$ 7.4. Cerebellums were dissected, post fixed in the same fixative overnight, and transferred to $30 \%$ sucrose solution for cryoprotection. Sagittal sections of $40 \mu \mathrm{m}$ thickness in each section of cerebellum were made with a freezing microtome (Leica, Nussloch, Germany).

\section{Immunohistochemistry for calbindinD-28k and GFAP}

For the detection of calbindin-positive and glial fibrillary acidic protein (GFAP)-positive cells in the cerebellar vermis, immunohistochemistry was performed. Briefly, the sections were incubated in PBS for 10 min and washed 3 times with PBS, and then incubated in $1 \%$ hydrogen peroxide $\left(\mathrm{H}_{2} \mathrm{O}_{2}\right)$ for $30 \mathrm{~min}$. Next, the sections were incubated overnight with mouse anti calbindin D-28k antibody (Sigma Chemical Co., St. Louis, MO, USA ) at a dilution of 1:1,000 for visualization of Purkinje cells or with mouse antiGFAP antibody (Chemicon, Temecula, CA, USA) at a dilution of 1:2,000 for visualization of astrocytes. The sections were then incubated for $1 \mathrm{~h}$ with anti-mouse secondary antibody (1:200; Vector Laboratories, Burlingame, CA, USA). Bound secondary antibody was then amplified with a Vector Elite $A B C$ kit $^{\circledR}$ (Vector Laboratories). The sections were subsequently incubated with avidin-biotin-peroxidase complex (1:100; Vector Laboratories) for $1 \mathrm{~h}$ at room temperature. Immunoreactivity was visualized by incubating the sections in a solution consisting of $0.05 \% 3,3$-diaminobenzidine (DAB) and $0.01 \% \mathrm{H}_{2} \mathrm{O}_{2}$ in $50 \mathrm{mM}$ Tris buffer $(\mathrm{pH}$ 7.6) for approximately $3 \mathrm{~min}$. The sections were then mounted on gelatin-coated glass slides. The slides were air-dried overnight at room temperature, and the coverslips were mounted using Permount ${ }^{\circledR}$.

\section{Western blot analysis}

Brains were collected at lobules VIII-X areas of the cerebellum, and then were immediately frozen at $-70^{\circ} \mathrm{C}$. Cerebellums were homogenized on ice, and lysed in a lysis buffer containing $50 \mathrm{mM}$
HEPES (pH 7.5), 150 mM NaCl, $10 \%$ glycerol, $1 \%$ Triton X-100, $1 \mathrm{mM}$ PMSF, $1 \mathrm{mM}$ EGTA, $1.5 \mathrm{mM} \mathrm{MgCl} \cdot 6 \mathrm{H}_{2} \mathrm{O}, 1 \mathrm{mM}$ sodium orthovanadate, and $100 \mathrm{mM}$ sodium flouride. Protein content was measured using a Bio-Rad colorimetric protein assay kit (Hercules, CA, USA). Protein $(30 \mu \mathrm{g})$ was separated on SDS-polyacrylamide gels and transferred onto a nitrocellulose membrane. Mouseactin antibody (1:3,000; Santa Cruz Biotechnology, Santa Cruz, CA, USA), mouse GFAP antibody (1:1,000; Santa Cruz Biotechnology), mouse Bax antibody (1:1,000; Santa Cruz Biotechnology), and mouse Bcl-2 antibody (1:1,000; Santa Cruz Biotechnology) were used as the primary antibodies. Horseradish peroxidaseconjugated anti-mouse antibody for actin, AP, Bax and Bcl-2 (1: 3,000; Vector Laboratories) were used as the secondary antibodies. Experiments were performed in normal laboratory conditions and at room temperature, except for the transferred membranes. Transferred membranes were performed at $4{ }^{\circ} \mathrm{C}$ with the cold pack and pre-chilled buffer. Band detection was performed using the enhanced chemiluminescence (ECL) detection kit (Santa Cruz Biotechnology). To compare the relative expression of proteins, the detected bands were calculated densitometrically using Image-Pro ${ }^{\circledR}$ Plus software (Media Cybernetics, Bethesda, MD, USA).

\section{Data analysis}

To quantify the number of Purkinje neurons three and four nonadjacent vermis sections per animal were chosen. Using ImagePro ${ }^{\circledR}$ Plus software (Media Cybernetics, Bethesda, MD), a 1,000 $\mu \mathrm{m}$ contour line was drawn along the Purkinje neuron layer on both sides of the fissure or gyrus. The number of Purkinje neurons for each sample was calculated as the average number of Purkinje neurons. Before beginning the image analysis, the light source was adjusted to the brightness generating the best possible contrast between positive and negative staining astrocytes. Quantification for Purkinje neurons was conducted in a blinded manner. All data are presented as the mean standard error of the mean (SEM). Statistical analysis for Purkinje cell quantification was done by ANOVA following Duncan's post hoc test using SPSS computer software (Version 18.0). The differences were considered significant at $P<0.05$.

\section{RESULTS}

\section{Effect of treadmill exercise on balance in the vertical pole} test

The vertical pole test was performed for 4 weeks after starting of experiment. The time score of the vertical pole test are present- 
ed in Fig. 1. The time score was $154.60 \pm 6.19 \mathrm{sec}$ in the control group, $57.60 \pm 3.20 \mathrm{sec}$ in the ADHD group, $149.80 \pm 20.08 \mathrm{sec}$ in the ADHD and MPH-treated group, and $137.60 \pm 8.85 \mathrm{sec}$ in the ADHD and treadmill exercise group. These results showed that the balance of the ADHD rats was lower than that of the control rats $(P<0.05)$. In contrast, treadmill exercise and MPH treatment significantly increased the balance of ADHD rats $(P<0.05)$.

\section{Effect of treadmill exercise on survival of Purkinje cells in the cerebellum}

The photomicrographs of the Purkinje neuronal cells in the gyrus of lobules VIII of the cerebellar vermis (dotted rectangle) are presented in Fig. 2A. The number of calbindin-positive Purkinje cells in the gyrus of lobules VIII of the cerebellar vermis was 56.85 \pm 1.51 /section in the control group, $27.23 \pm 1.29 /$ section in the ADHD group, 47.01 $\pm 2.27 /$ section in the ADHD and MPHtreated group, and $44.28 \pm 0.83 /$ section in the ADHD and treadmill exercise group (Fig 2B). These results showed that the number of calbindin-positive cells in the cerebellum of the ADHD rats was significantly decreased compared to that of the control rats $(P<0.05)$, and that treadmill exercise and MPH treatment significantly prevented death of Purkinje neurons $(P<0.05)$.

\section{Effect of treadmill exercise on GFAP protein expression in the cerebellum}

The photomicrographs of GFAP-positive cells in both the gran-

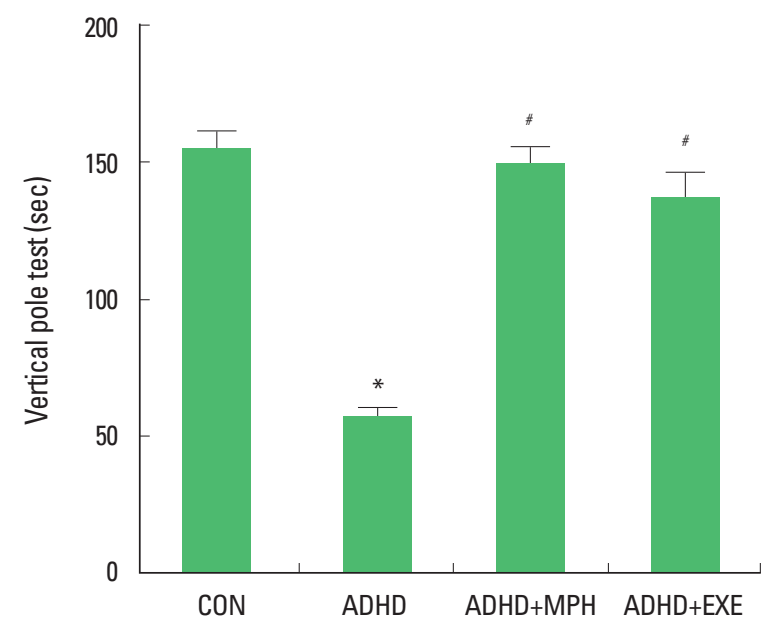

Fig. 1. Effects of treadmill exercise on vertical pole test. (CON) control group, $(\mathrm{ADHD})$ attention deficit/hyperactivity disorder group, (ADHD+MPH), attention deficit/hyperactivity disorder and methylphenidate-treated group, (ADHD+EXE), attention deficit/hyperactivity disorder and treadmill exercise group. ${ }^{*} P<0.05$ compared with the control group. ${ }^{\#} P<0.05$ compared with the $A D H D$ group. The data are expressed as the mean \pm SEM. ule layers of cerebellar vermis are presented in Fig. 3A. The level of GFAP protein in the cerebellum was analyzed by Western blotting (Fig. 3B). When the level of mature GFAP $(55 \mathrm{kDa})$ in the control group was set as $1.00 \pm 0.0$, the level of mature GFAP was $1.43 \pm 0.33$ in the ADHD group, $1.00 \pm 0.00$ in the ADHD and MPH-treated group, and $1.02 \pm 0.06$ in the ADHD and treadmill exercise group. The number of GFAP-positive cells in the gyrus of lobules VIII of the cerebellar vermis was increased when compared to the control group. In contrast, the GFAP-positive cells was decreased by treadmill exercise and MPH treatment (Fig. 3C). These results showed that the GFAP expression in the cerebellums
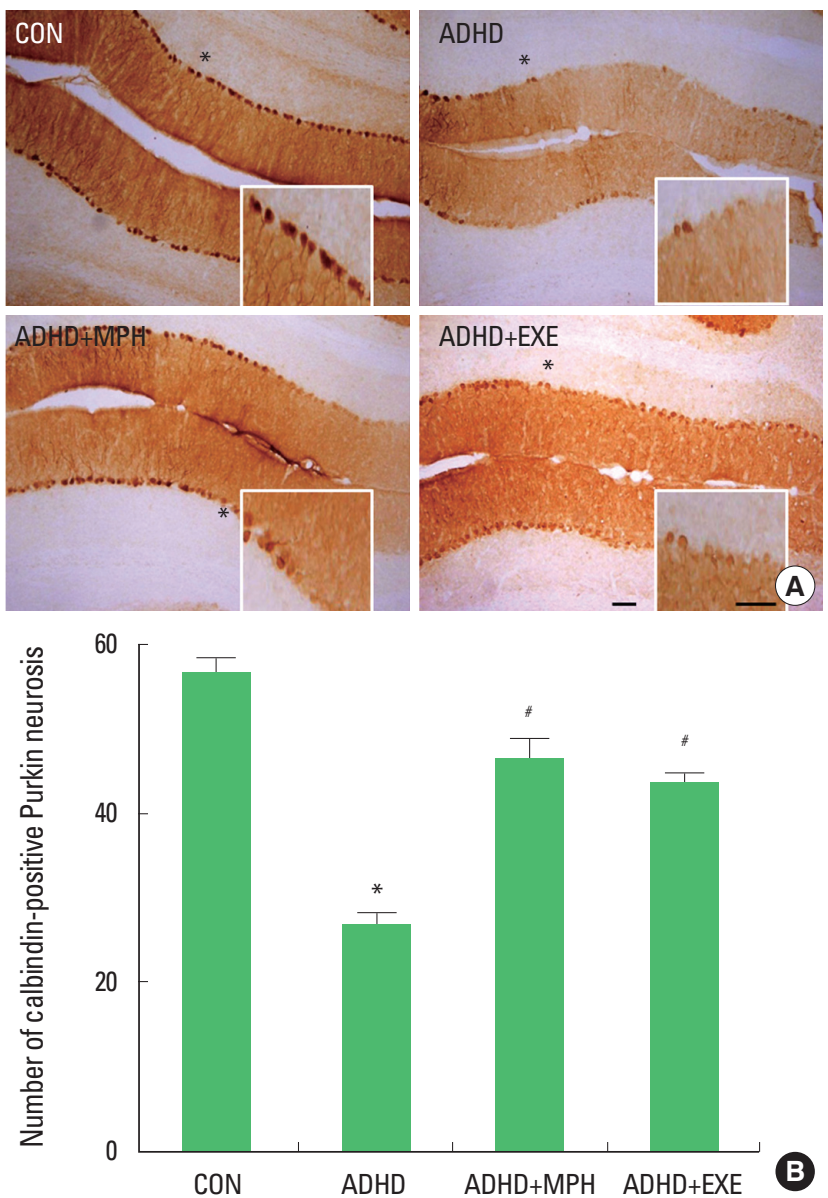

Fig. 2. Effects of treadmill exercise on surviving Purkinje cells in the cerebellular vermis. (A) Photomicrographs of a sagittal section Purkinje cells in the cerebellum. The sections were stained for Purkinje cells immunoreactivity with calbindin D-28k (brown). The scale bar represents $200 \mu \mathrm{m}$. (B) The mean number of calbindin-positive Purkinje cells in each group. (CON) control group, (ADHD) attention deficit/hyperactivity disorder group, (ADHD+MPH), attention deficit/ hyperactivity disorder and MPH-treated group, (ADHD+EXE), attention deficit/ hyperactivity disorder and treadmill exercise group. ${ }^{*} P<0.05$ compared with the control group. ${ }^{\sharp} P<0.05$ compared with the ADHD group. The data are expressed as the mean \pm SEM. 

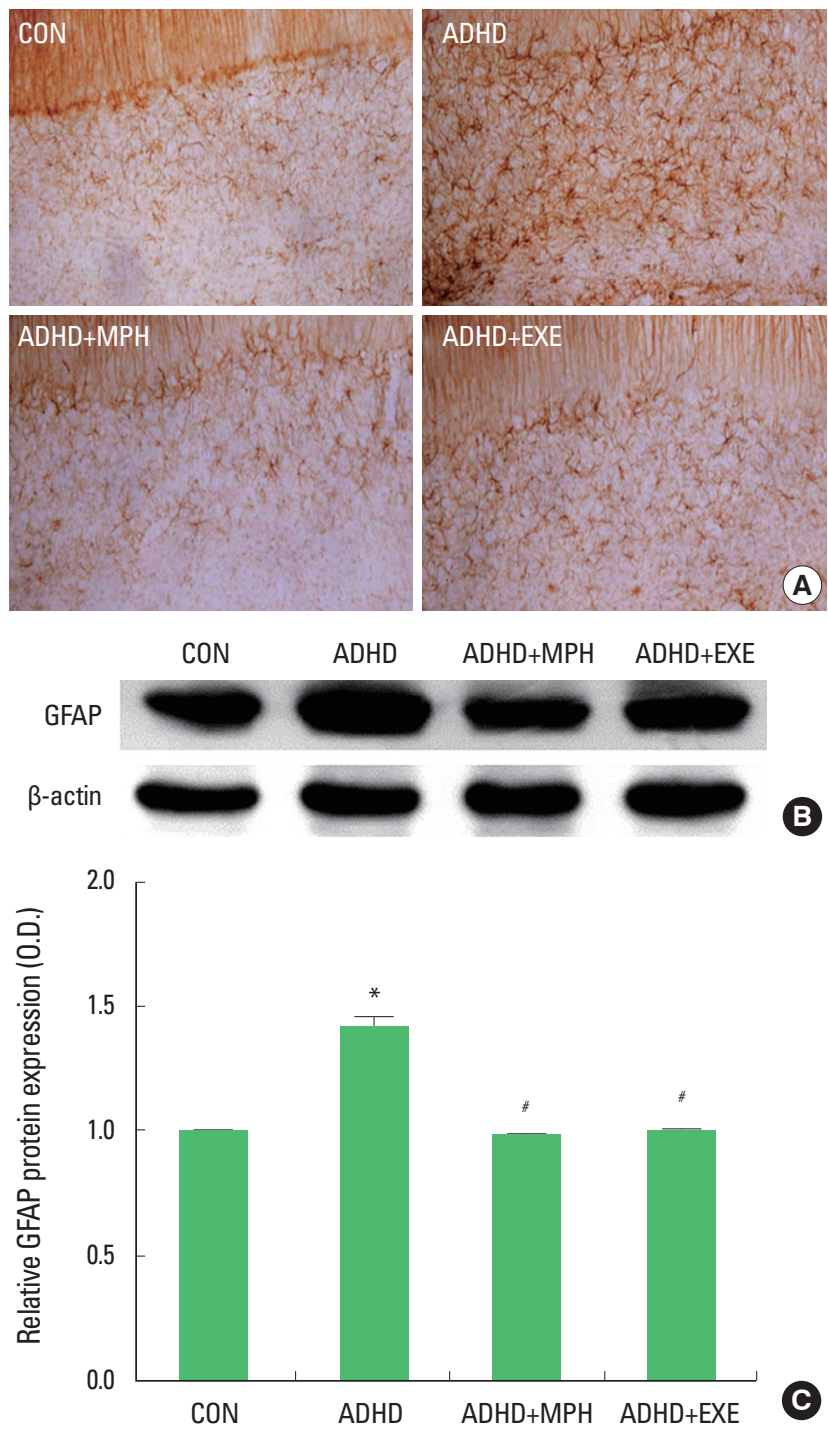

Fig. 3. Effects of treadmill exercise on activation of the reactive astrocytes in the cerebellular vermis. (A) Photomicrographs of GFAP-positive reactive astrocytes in molecular layer of the cerebellum. The sections were stained for GFAP immunoreactivity (brown). The scale bar represents $200 \mu \mathrm{m}$. (B) Western blot analysis of GFAP protein in the cerebellar vermis. (C) The mean optical density of reactive astrocytes in each group. (CON) control group, (ADHD) attention deficit/hyperactivity disorder group, (ADHD+MPH), attention deficit/hyperactivity disorder and MPH-treated group, (ADHD+EXE), attention deficit/hyperactivity disorder and treadmill exercise group. ${ }^{*} P<0.05$ compared with the control group. ${ }^{\#} P<0.05$ compared with the $\mathrm{ADHD}$ group. The data are expressed as the mean \pm SEM.

of the ADHD rats was significantly increased compared to that of the control rats $(P<0.05)$, and that treadmill exercise and $\mathrm{MPH}$ treatment significantly decreased GFAP expression in the cerebel$\operatorname{lum}(P<0.05)$.

\section{Effect of treadmill exercise on Bax and Bcl-2 protein} expression in the cerebellums

The level of $\mathrm{Bax}$ and $\mathrm{Bcl}-2$ protein in the cerebellum were analyzed by Western blotting (Fig. 4A). Bax expression is presented in Fig 4B. When the level of mature $\mathrm{Bax}(21 \mathrm{kDa})$ in the control group was set as $1.00 \pm 0.0$, the level of mature Bax was $2.83 \pm$ 0.18 in the ADHD group, $1.22 \pm 0.18$ in the ADHD and MPHtreated group, and $1.45 \pm 0.39$ in the ADHD and treadmill exercise group. Bcl-2 expression is presented in Fig 4C. When the level of mature $\mathrm{Bcl}-2(26 \mathrm{kDa})$ in the control group was set as 1.00 \pm 0.0 , the level of mature $\mathrm{Bcl}-2$ was $0.43 \pm 0.10$ in the $\mathrm{ADHD}$ group, $0.92 \pm 0.09$ in the ADHD and MPH-treated group, and $0.86 \pm 0.13$ in the ADHD and treadmill exercise group. The ratio of $\mathrm{Bax} / \mathrm{Bcl}-2$ protein expression is presented in Fig. 4D. When the level of mature $\mathrm{Bax} / \mathrm{Bcl}-2$ ratio in the control group was set as $1.00 \pm 0.0$, the level of mature $\mathrm{Bax} / \mathrm{Bcl}-2$ ratio was $10.84 \pm 2.79$ in the ADHD group, $1.50 \pm 0.27$ in the ADHD and $\mathrm{MPH}$-treated group, and $2.38 \pm 0.73$ in the ADHD and treadmill exercise group. These results showed that the expression of Bax protein in the ADHD rats was significantly higher than that in the control rats $(P<$ $0.05)$, while treadmill exercise and MPH treatment suppressed the Bax protein expression in the cerebellum $(P<0.05)$. The expression of $\mathrm{Bcl}-2$ protein in the ADHD rats was significantly lower than that in the control rats $(P<0.05)$, while treadmill exercise and $\mathrm{MPH}$ treatment enhanced the $\mathrm{Bcl}-2$ protein expression in the cerebellum $(P<0.05)$. The ratio of $\mathrm{Bax} / \mathrm{Bcl}-2$ protein expression in the ADHD rats was significantly higher than that in the control rats $(P<0.05)$, while treadmill exercise and MPH treatment suppressed the ratio of $\mathrm{Bax} / \mathrm{Bcl}-2$ protein expression in the cerebellum $(P<0.05)$.

\section{DISCUSSION}

The cerebellum is a major structures involved in motor learning, motor coordination and control by maintaining a balance and muscle tension (Ito, 2000; Lee et al., 2007; Thompson et al., 1995). A few studies suggested that dysregulation within cerebellar circuits may contribute to the symptoms of ADHD such as attention deficit and impairment of motor coordination (Buderath et al., 2009; Hart et al., 2012). Buderath et al. (2009) reported that cerebellar dysfunction in children with ADHD induces the postural and gait deficits such as static and dynamic balance. Hart et al. (2012) also showed that consistent and replicable deficits of timing function were observed in patients with ADHD. In this study, ADHD rats showed significantly lower balance than the 


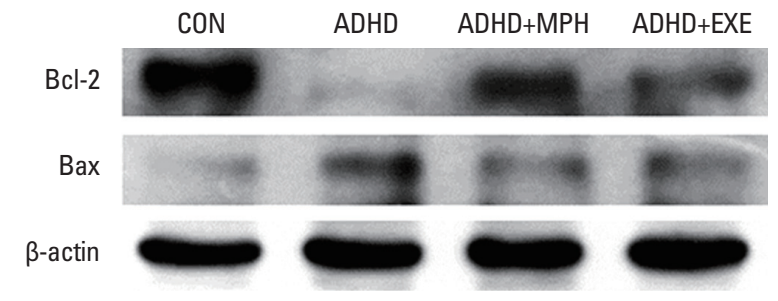

A

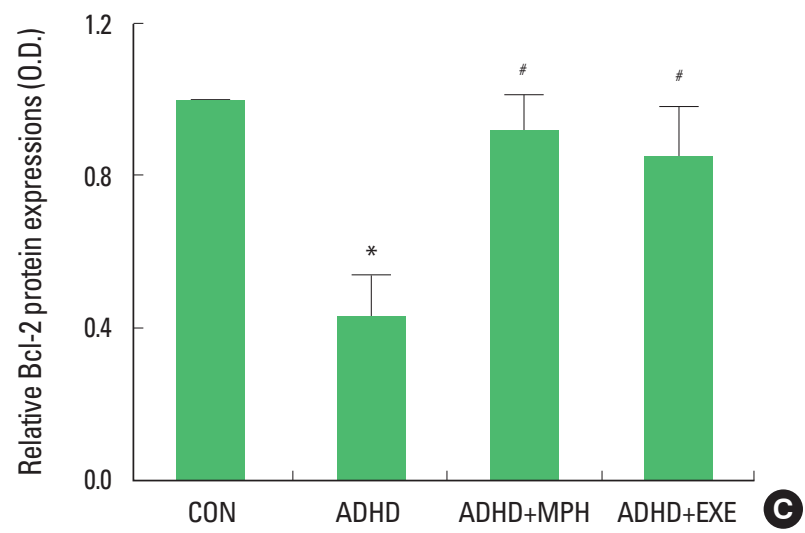

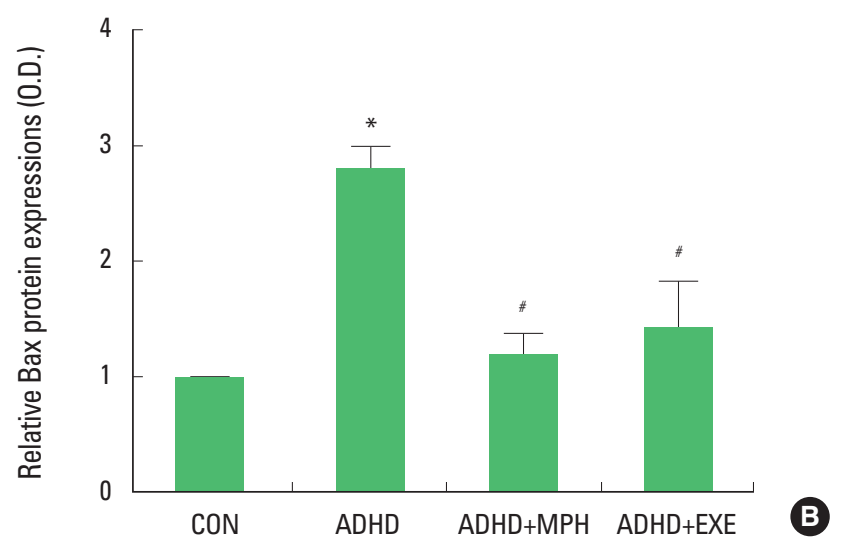

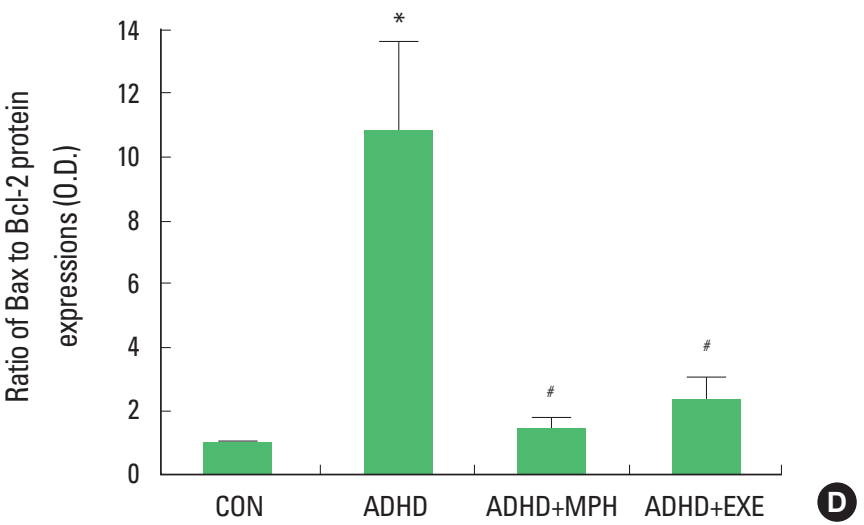

Fig. 4. Effects of treadmill exercise on the expression of Bcl-2 and Bax protein. (A) Western blot analysis of Bcl-2 and Bax protein in the cerebellum. (B) The mean optical density of Bax expression in each group. (C) The mean optical density of Bcl-2 expression in each group. (D) The Bax/Bcl-2 ratio in each group. (CON) control group, $(\mathrm{ADHD})$ attention deficit/ hyperactivity disorder group, (ADHD+MPH), attention deficit/hyperactivity disorder and MPH- treated group, (ADHD+EXE), attention deficit/ hyperactivity disorder and treadmill exercise group. ${ }^{*} P<0.05$ compared with the control group. ${ }^{\sharp} P<0.05$ compared with the ADHD group. The data are expressed as the mean \pm SEM.

control rats in the vertical pole test. Together with previous studies, our result supported the hypothesis that ADHD may be closely associated with the dysfunction of cerebellum leading to motor deficit like balance problem.

Although the precise mechanism on occurrence of cerebellar dysfunction by ADHD was not fully understood to date, previous studies reported the relevance that the Purkinje cells of cerebellar cortex is closely related to the motor function (Black et al., 1990; Kleim et al., 1998; Zhang et al., 2013). Black et al. (1990) showed that the increased number of synapses of Purkinje cell was attributable to the increase of motor learning. Kleim et al. (1998) reported that the learned complex motor skills increase the number of synapses on Purkinje cells in the adult rats. In contrast, Zhang et al. (2013) supported the idea that impairment of motor coordination and motor learning is closely associated with the dysfunction of cerebellar Purkinje cells in mouse. In particular, several structural imaging studies have consistently reported that the cerebellar abnormalities such as reduced volume and smaller ana- tomic areas of cerebellum were observed in adult and children with ADHD (Ashtari et al., 2005; Castellanos et al., 2002; SemrudClikeman et al., 2000). Recently, Passarelli et al. (2013) suggested that the immune dysregulation of the Purkinje cell of the cerebellum is associated with the onset of ADHD in children. Similar to the previous studies, we observed the increased expressions of apoptotic factors such as Bax, $\mathrm{Bcl}-2$ and the increased astrocytic factor such as GFAP in Purkinje cells of the cerebellar vermis in ADHD group. That is, ADHD increased apoptosis and astrogliosis in Purkinje cell of the cerebellum, which is induced Purkinje cell loss in the cerebellum. Therefore, our results supported the idea that the symptoms of ADHD might be induced by the death or dysfunction of Purkinje neurons in part.

It has been widely accepted that regular exercise plays a crucial role to enhance brain structure and cognitive function. Regular exercise increased neuronal survival, learning, and memory (Chae et al., 2012; Kim et al., 2010a, 2010b). It also alleviated traumatic brain injury (Seo et al., 2010), and reduced the symptoms of 
brain disorder such as Parkinson's disease, Alzheimer's disease, and ADHD (Kim et al., 2011; Majorek et al., 2004; O'Dell et al., 2007; Petzinger et al., 2007). In addition, several studies demonstrate that regular exercise enhanced attention and concentration performance (Budde et al., 2008; Hillman et al., 2009). Related to AD$\mathrm{HD}$, a few studies have reported the possible effect of exercise on ADHD (Gapin and Etnier, 2010; Majorek et al., 2004; Medina et al., 2010; Park et al., 2013; Tantillo et al., 2002). Tantillo et al. (2002) suggested that motor impersistence was decreased by maximal exercise in boys with ADHD. Majorek et al. (2004) showed that physical movement improved working speed and diminished hyperactivity in children with ADHD. Similar to the previous studies, we demonstrated that treadmill exercise recovered balance ability through the reduction of Purkinje cell loss and astrocytic reaction in the cerebellar vermis in rat with symptoms of ADHD and its effect indicated similar level with medication, MPH. These results supported the possibility that regular exercise might be an effective interventional program to reduce problematic behaviors in ADHD through inhibiting Purkinje cell loss in cerebellum.

Although the interesting results of treadmill exercise on ADHD, there was limitation of the current study. Primary limitation is that there is no criteria on the level of balance ability for ADHD animal model. For this reason, the present behavioral results did not explain directly whether the decreased level of balance ability in ADHD group is associated with symptoms of ADHD or not. It is required to examine various types of behaviors for searching adequate behavior test. In sum, treadmill exercise might exert ameliorating effect on ADHD through reduction of Purkinje cell loss and astrocytic reaction in the cerebellum.

\section{CONFLICT OF INTEREST}

No potential conflict of interest relevant to this article was reported.

\section{ACKNOWLEDGMENTS}

This work was supported by the National Research Foundation of Korea Grant funded by the Korean Government (NRF-2011327-G00121).

\section{REFERENCES}

Ashtari M, Kumra S, Bhaskar SL, Clarke T, Thaden E, Cervellione KL, Rhinewine J, Kane JM, Adesman A, Milanaik R, Maytal J, Diamond A,
Szeszko P, Ardekani BA. Attention-deficit/hyperactivity disorder: A preliminary diffusion tensor imaging study. Biol Psychiatry 2005;57: 448-455.

Banaschewski T, Roessner V, Dittmann RW, Santosh PJ, Rothenberger A. Non-stimulant medications in the treatment of ADHD. Eur Child Adolesc Psychiatry 2004;13 Suppl 1:I102-16.

Bedford TG, Tipton CM, Wilson NC, Oppliger RA, Gisolfi CV. Maximum oxygen consumption of rats and its changes with various experimental procedures. J Appl Physiol Respir Environ Exerc Physiol 1979;47: 1278-1283.

Berquin PC, Giedd JN, Jacobsen LK, Hamburger SD, Krain AL, Rapoport JL, Castellanos FX. Cerebellum in attention-deficit hyperactivity disorder: A morphometric MRI study. Neurology 1998;50:1087-1093.

Berridge CW, Devilbiss DM, Andrzejewski ME, Arnsten AF, Kelley AE, Schmeichel B, Hamilton C, Spencer RC. Methylphenidate preferentially increases catecholamine neurotransmission within the prefrontal cortex at low doses that enhance cognitive function. Biol Psychiatry 2006;60:1111-1120.

Bethancourt JA, Camarena ZZ, Britton GB. Exposure to oral methylphenidate from adolescence through young adulthood produces transient effects on hippocampal-sensitive memory in rats. Behav Brain Res 2009;202:50-57.

Black JE, Isaacs KR, Anderson BJ, Alcantara AA, Greenough WT. Learning causes synaptogenesis, whereas motor activity causes angiogenesis, in cerebellar cortex of adult rats. Proc Natl Acad Sci U S A 1990; 87:5568-5572.

Budde H, Voelcker-Rehage C, Pietraßyk-Kendziorra S, Ribeiro P, Tidow G. Acute coordinative exercise improves attentional performance in adolescents. Neurosci Lett 2008;441:219-223.

Buderath P, Gartner K, Frings M, Christiansen H, Schoch B, Konczak J, Gizewski ER, Hebebrand J, Timmann D. Postural and gait performance in children with attention deficit/hyperactivity disorder. Gait Posture 2009;29:249-254.

Castellanos FX, Lee PP, Sharp W, Jeffries NO, Greenstein DK, Clasen LS, Blumenthal JD, James RS, Ebens CL, Walter JM, Zijdenbos A, Evans AC, Giedd JN, Rapoport JL. Developmental trajectories of brain volume abnormalities in children and adolescents with attention-deficit/ hyperactivity disorder. Jama 2002;288:1740-1748.

Chae CH, Lee HC, Jung SL, Kim TW, Kim JH, Kim NJ, Kim HT. Swimming exercise increases the level of nerve growth factor and stimulates neurogenesis in adult rat hippocampus. Neuroscience 2012;212:30-37.

De Smet HJ, Paquier P, Verhoeven J, Marien P. The cerebellum: Its role in language and related cognitive and affective functions. Brain Lang 2013;127:334-342.

Erickson KI, Gildengers AG, Butters MA. Physical activity and brain plas- 
ticity in late adulthood. Dialogues Clin Neurosci 2013;15:99-108.

Fukutani Y, Cairns NJ, Rossor MN, Lantos PL. Purkinje cell loss and astrocytosis in the cerebellum in familial and sporadic alzheimer's disease. Neurosci Lett 1996;214:33-36.

Gapin J, Etnier JL. The relationship between physical activity and executive function performance in children with attention-deficit hyperactivity disorder. J Sport Exerc Psychol 2010;32:753-763.

Giedd JN, Blumenthal J, Molloy E, Castellanos FX. Brain imaging of attention deficit/hyperactivity disorder. Ann N Y Acad Sci 2001;931:3349.

Hart H, Radua J, Mataix-Cols D, Rubia K. Meta-analysis of fMRI studies of timing in attention-deficit hyperactivity disorder (ADHD). Neurosci Biobehav Rev 2012;36:2248-2256.

Hillman CH, Pontifex MB, Raine LB, Castelli DM, Hall EE, Kramer AF. The effect of acute treadmill walking on cognitive control and academic achievement in preadolescent children. Neuroscience 2009;159:10441054.

Ito M. Mechanisms of motor learning in the cerebellum. Brain Res 2000; 886:237-245.

Ivry RB, Spencer RM, Zelaznik HN, Diedrichsen J. The cerebellum and event timing. Ann N Y Acad Sci 2002;978:302-317.

Jones J, Jaramillo-Merchán J, Bueno C, Pastor D, Viso-León M, Martínez S. Mesenchymal stem cells rescue purkinje cells and improve motor functions in a mouse model of cerebellar ataxia. Neurobiol Dis 2010;40:415423.

Kim DH, Ko IG, Kim BK, Kim TW, Kim SE, Shin MS, Kim CJ, Kim H, Kim KM, Baek SS. Treadmill exercise inhibits traumatic brain injury-induced hippocampal apoptosis. Physiol Behav 2010a;101:660-665.

Kim H, Heo HI, Kim DH, Ko IG, Lee SS, Kim SE, Kim BK, Kim TW, Ji ES, Kim JD, Shin MS, Choi YW, Kim CJ. Treadmill exercise and methylphenidate ameliorate symptoms of attention deficit/hyperactivity disorder through enhancing dopamine synthesis and brain-derived neurotrophic factor expression in spontaneous hypertensive rats. Neurosci Lett 2011;504:35-39.

Kim SE, Ko IG, Kim BK, Shin MS, Cho S, Kim CJ, Kim SH, Baek SS, Lee EK, Jee YS. Treadmill exercise prevents aging-induced failure of memory through an increase in neurogenesis and suppression of apoptosis in rat hippocampus. Exp Gerontol 2010b;45:357-365.

Kleim JA, Swain RA, Armstrong KA, Napper RM, Jones TA, Greenough WT. Selective synaptic plasticity within the cerebellar cortex following complex motor skill learning. Neurobiol Learn Mem 1998;69:274-289.

Lee KJ, Jung JG, Arii T, Imoto K, Rhyu IJ. Morphological changes in dendritic spines of purkinje cells associated with motor learning. Neurobiol Learn Mem 2007;88:445-450.

Lijffijt M, Kenemans JL, Verbaten MN, van Engeland H. A meta-analytic review of stopping performance in attention-deficit/hyperactivity disorder: Deficient inhibitory motor control? J Abnorm Psychol 2005;114: 216-222.

Lu H, Levis H, Liu Y, Parker T. Organotypic slices culture model for cerebellar ataxia: Potential use to study purkinje cell induction from neural stem cells. Brain Res Bull 2011;84:169-173.

Mackie S, Shaw P, Lenroot R, Pierson R, Greenstein DK, Nugent TF,3rd, Sharp WS, Giedd JN, Rapoport JL. Cerebellar development and clinical outcome in attention deficit hyperactivity disorder. Am J Psychiatry 2007;164:647-655.

Majorek M, Tuchelmann T, Heusser P. Therapeutic eurythmy-movement therapy for children with attention deficit hyperactivity disorder (ADHD): A pilot study. Complement Ther Nurs Midwifery 2004;10:46-53.

Medina JA, Netto TL, Muszkat M, Medina AC, Botter D, Orbetelli R, Scaramuzza LF, Sinnes EG, Vilela M, Miranda MC. Exercise impact on sustained attention of ADHD children, methylphenidate effects. Atten Defic Hyperact Disord 2010;2:49-58

O'Dell SJ, Gross NB, Fricks AN, Casiano BD, Nguyen TB, Marshall JF. Running wheel exercise enhances recovery from nigrostriatal dopamine injury without inducing neuroprotection. Neuroscience 2007;144:11411151.

Park MS, Byun KW, Park YK, Kim MH, Jung SH, Kim H. Effect of complex treatment using visual and auditory stimuli on the symptoms of attention deficit/hyperactivity disorder in children. J Exerc Rehabil 2013;9:316-325.

Passarelli F, Donfrancesco R, Nativio P, Pascale E, Di Trani M, Patti AM, Vulcano A, Gozzo P, Villa MP. Anti-purkinje cell antibody as a biological marker in attention deficit/hyperactivity disorder: A pilot study. J Neuroimmunol 2013;258:67-70.

Petzinger GM, Walsh JP, Akopian G, Hogg E, Abernathy A, Arevalo P, Turnquist P, Vuckovic M, Fisher BE, Togasaki DM, Jakowec MW. Effects of treadmill exercise on dopaminergic transmission in the 1-methyl-4-phenyl-1,2,3,6-tetrahydropyridine-lesioned mouse model of basal ganglia injury. J Neurosci 2007;27:5291-5300.

Radak Z, Kaneko T, Tahara S, Nakamoto H, Pucsok J, Sasvari M, Nyakas C, Goto S. Regular exercise improves cognitive function and decreases oxidative damage in rat brain. Neurochem Int 2001;38:17-23.

Sagvolden T. Behavioral validation of the spontaneously hypertensive rat (SHR) as an animal model of attention-deficit/hyperactivity disorder (AD/HD). Neurosci Biobehav Rev 2000;24:31-39.

Schmahmann JD, Sherman JC. The cerebellar cognitive affective syndrome. Brain 1998;121 ( Pt 4):561-579.

Semrud-Clikeman M, Steingard RJ, Filipek P, Biederman J, Bekken K, Renshaw PF. Using MRI to examine brain-behavior relationships in males with attention deficit disorder with hyperactivity. J Am Acad Child 
Adolesc Psychiatry 2000;39:477-484.

Seo TB, Kim BK, Ko IG, Kim DH, Shin MS, Kim CJ, Yoon JH, Kim H. Effect of treadmill exercise on purkinje cell loss and astrocytic reaction in the cerebellum after traumatic brain injury. Neurosci Lett 2010;481: 178-182.

Soliva JC, Carmona S, Fauquet J, Hoekzema E, Bulbena A, Hilferty J, Vilarroya $\mathrm{O}$. Neurobiological substrates of social cognition impairment in attention-deficit hyperactivity disorder: Gathering insights from seven structural and functional magnetic resonance imaging studies. Ann N Y Acad Sci 2009;1167:212-220.

Tanriover G, Seval-Celik Y, Ozsoy O, Akkoyunlu G, Savcioglu F, Hacioglu G, Demir N, Agar A. The effects of docosahexaenoic acid on glial derived neurotrophic factor and neurturin in bilateral rat model of parkinson's disease. Folia Histochem Cytobiol 2010;48:434-441.

Tantillo M, Kesick CM, Hynd GW, Dishman RK. The effects of exercise on children with attention-deficit hyperactivity disorder. Med Sci Sports Exerc 2002;34:203-212.

Thompson CB. Apoptosis in the pathogenesis and treatment of disease. Science 1995;267:1456-1462.

Wang S, Yang Y, Xing W, Chen J, Liu C, Luo X. Altered neural circuits related to sustained attention and executive control in children with ADHD: An event-related fMRI study. Clin Neurophysiol 2013;124:21812190.

Zhang L, Chung SK, Chow BK. The knockout of secretin in cerebellar purkinje cells impairs mouse motor coordination and motor learning. Neuropsychopharmacology 2013;doi:10.1038/npp.2013.344. 